\title{
Chemical treatment of roughage
}

\section{Aureliano José Vieira Pires ${ }^{1}$, Gleidson Giordano Pinto de Carvalho ${ }^{2}$, Leandro Sampaio Oliveira Ribeiro ${ }^{3}$}

\author{
${ }^{1}$ DTRA/UESB \\ 2 DPA/UFBA. \\ 3 Pós-Graduação - UESB
}

ABSTRACT - Chemical treatment of roughage has been the aim of studies for a long time. However, until nowadays, many questions are arisen due to the efficiency of additives used in relation to the variation of answers, either in nutritive value of treated roughage or in performance of animals feed with diet containing such roughage. This revision will approach the main and most used products, which are anhydrous ammonia, urea, sodium hydroxide and calcium oxide. It has been noticed that ammonization (both for anhydrous ammonia and urea) has presented more efficient result in animal's performance when compared with sodium hydroxide or calcium oxide. However, regarding its nutritive value, both sodium hydroxide and calcium oxide have presented a higher efficiency in the decreasing of cell wall and in the increase of treated roughage' digestibility.

Key Words: ammonia, calcium oxide, sodium hydroxide, urea

\section{Tratamento químico de volumosos}

RESUMO - O tratamento químico de volumosos tem sido objeto de estudos há muito tempo. Entretanto, até hoje muitas dúvidas são levantadas sobre a eficiência dos aditivos utilizados no que se refere à variação das respostas seja no valor nutritivo dos volumosos tratados, seja no desempenho dos animais alimentados com dietas contendo estes volumosos. Esta revisão abordará os principais e mais utilizados produtos químicos, que são a amônia anidra, a uréia, o hidróxido de sódio e o óxido de cálcio. Tem-se verificado que a amonização (tanto com amônia anidra quanto uréia) tem apresentado resultados mais eficientes no desempenho animal quando comparada ao hidróxido de sódio ou óxido de cálcio. Entretanto, em relação ao valor nutritivo, tanto o hidróxido de sódio quanto o óxido de cálcio têm apresentado maior eficiência na redução da parede celular e no aumento da digestibilidade de volumosos tratados.

Palavras-chave: amônia, hidróxido de sódio, óxido de cálcio, uréia

\section{Introduction}

The search for alternative foods for ruminants beyond pasture, silage and hay is a reality in Brazil's production system. Therefore, residues and sub-products assume a great importance in animal's production system, since that supply is the most difficult item on this system. In the case of silage and hay production, those could be produced with the own surplus of forage's production during the raining season, while residues and sub-products would depend of region's availability. In spite of have potential to supply some needs of ruminants, the residues and sub-products commonly have a poor nutritive and protein values and a high fiber value.

Chemical treatment then appears as an option to improve the nutritive value of forage. Many research works are mentioning the benefits of this practice (Pires et al., 2004;
Bertipaglia et al., 2005; Ezequiel et al., 2005; Pires et al., 2006a,b; Ribeiro et al., 2009).

Chemical treatment of roughage is not a recently thing. Fingerlin et al. (1923) mentioned by Homb (1984) already have reported increases on organic matter digestibility of rye straw when treated with sodium hydroxide $(\mathrm{NaOH})$. However, researches with animal's performance data and costs assessment must be done to adopt such practice.

In this revision we will discuss the aspects related to the chemical treatment of roughage, focusing ammonization (treatment with urea or anhydrous ammonia), treatments with sodium hydroxide or calcium oxide in different roughage that are potentially used for ruminants' feeding.

\section{Conservation}

Among the chemical products used for forages conservation, urea and anhydrous ammonia $\left(\mathrm{NH}_{3}\right)$ are the 
most used ones. One of the reasons to use these products for fodder maintenance is due their fungicide and bacteriostatic effect that they have over the forage stored at moisture over $20 \%$, and in addition of providing nonprotein nitrogen that can be used by rumen microorganism for microbial protein synthesis. Pires et al. (1990) verified that $\mathrm{NH}_{3}$ doses of 2 and $3 \%$ were efficient for the conservation of ground corn at high moisture while the untreated material or just treated with $\mathrm{NH}_{3} 1 \%$ visually presented fungus.

We had noticed that normally the addition of $\mathrm{NH}_{3}$ doses over $1 \%$ (\%DM) is enough for material's conservation. On the other hand, for the conservation of materials using urea, we need to use doses over 4\% (\%DM).

Chemical products as sodium hydroxide $(\mathrm{NaOH})$ and calcium oxide $(\mathrm{CaO})$ can also be used for forage's conservation. In a recent work made by Ferreira (2005), the author verified that the addition of $4 \%$ of $\mathrm{NaOH}$ or urea was enough to keep the brix degree of silage in sugar cane, presenting values of 16.1 and 10.7 while sugar cane in natura presented a brix degree value of 17 (Table 1).

The association of these two additives $(2 \% \mathrm{NaOH}+2 \%$ urea) was also efficient for the conservation of brix degree, confirming the value of 15 units.

Balieiro Neto et al. (2007), evaluating CaO doses (0, 0.5, 1 and $2 \%$, based in NM) as additive for sugar cane silage, verified that the $\mathrm{CaO}$ dose of $2 \%$ was the one that promoted a higher recovery of dry matter (88.8\%). According to these authors, the higher recovery of dry matter means the maintaining of silage's nutritive value when compare to original forage. With these results, we noticed that $\mathrm{CaO}$ presents potential to be used as additive for the quality maintenance of sugar cane silage.

Table 1 - Average values of brix degree of silage in two sugar cane varieties that were submitted to different additives

\begin{tabular}{|c|c|c|c|}
\hline \multirow[t]{2}{*}{ Additive } & \multicolumn{2}{|c|}{ Variety } & \multirow[t]{2}{*}{ Average } \\
\hline & CB $45-3$ & RB 72-454 & \\
\hline \multicolumn{4}{|c|}{ Brix degree } \\
\hline Control & $7.5 b C$ & $9.5 \mathrm{aC}$ & 8.5 \\
\hline Urea $4 \%$ & $10.3 \mathrm{aB}$ & 11.3аB & 10.7 \\
\hline $\mathrm{NaOH} 4 \%$ & $17.5 \mathrm{aA}$ & $14.8 \mathrm{bA}$ & 16.1 \\
\hline Urea $2 \%+\mathrm{NaOH} 2 \%$ & 16.3aA & $13.8 \mathrm{bA}$ & 15.0 \\
\hline Average & 12.9 & 12.3 & \\
\hline$C V(\%)=7.0$ & & & \\
\hline
\end{tabular}

Averages followed by the same lowercase/uppercase in a same line/column do not differ by Tukey test of probability at $5 \%$.
Roughage treated with anhydrous ammonia $\left(\mathrm{NH}_{3}\right)$ or urea

Ammonization both with $\mathrm{NH}_{3}$ and urea has presented satisfactory results both in the modification of chemical composition as in animals' performance. However, some factors are responsible for higher or lower ammonization efficiency and those factors can influence the process in isolation or combination. The main factors that will be discussed are: nitrogen doses that are applied, treatment periods, ambient temperature, moisture of material to be treated, quality of material, and nitrogen source.

Nitrogen dose was one of the first factors assessed in the study of roughage's ammonization. And in general it has been observed that $\mathrm{NH}_{3}$ doses over $4 \%$ and urea doses of $7.5 \%$ normally are not used, because from these doses there is no longer response in quality's improvement. Besides, the highest nitrogen losses occur through the volatilization, when silos and stacks were opened. However, these values are used when we need to improve forage because such forage presents a poor digestibility. Lower doses of $\mathrm{NH}_{3}$ and urea are used when we want to maintain forage with moisture over $18 \%$ and below $50 \%$. In such case we normally use $\mathrm{NH}_{3}$ at 1.0 to $1.5 \%$ and urea at 1.9 to $2.8 \%$ based in forage's dry matter.

Another factor is the treatment period, which is closely linked to ambient temperature. Literature has been reported that at higher temperatures, around $30^{\circ} \mathrm{C}$, the ammonization period can be a week while when the temperature is lower as $5^{\circ} \mathrm{C}$, it would take at least two months for ammonization be effective.

In a research work made by Reis et al. (1991), aiming to verify the effects from two ammonization periods (30 and 45 days) and four $\mathrm{NH}_{3}$ doses (0, 2.0, 4.0 and 6.0\%) over the chemical composition of Brachiaria decumbens and Melinis minutiflora hays and that were harvest at postflowering stage, they verified that $\mathrm{CP}$ and ADIN values increased due ammonization, specially for $\mathrm{NH}_{3}$ doses of 4.0 and $6.0 \%$. Regardless $\mathrm{NH}_{3}$ doses, they did not notice any effect from ammonization period over nitrogen's retention in hays of both species, probably due the fact that the difference between ammonization periods is small. Authors still reported that the average ambient temperature of $20.5^{\circ} \mathrm{C}$ during the ammonization period allowed an adequate reaction between ammonia and treated material with 30 days of ammonization.

Material's moisture is another factor that has a remarkable effect because ammonia has high affinity with water. However, if the material has high moisture as silage, 
the material's compression must be taken into account due a low $\mathrm{NH}_{3}$ diffusion when applied on silos. Neiva et al. (1998a) reported these problems when they submitted corn silage containing 35 and $45 \%$ of DM to $1.2 \%$ of $\mathrm{NH}_{3}$ (DM base). On the other hand, materials as hays and straws have presented less nitrogen retention when ammonized. We must highlight the moisture importance in material treated with urea, which in addition to urease enzyme also needs moisture for ureolysis that will result in $\mathrm{NH}_{3}$ production. The minimum moisture generally recommended by literature is around $30 \%$, and forage up to $50 \%$ of moisture can be used with satisfactory results.

According to Dolberg (1992) the major efficiency in urea treatment can be obtained when forage has moisture value around $30 \%$ and urea is applied at 4.0 to $8.0 \%$ dosage of roughage dry matter.

Another factor that affects ammonization response is the nutritive value. Forages presenting poor nutritive value when ammonized usually present better results when compared to forages presenting high nutritive values. This is because that both present high digestibility and low levels of cell wall constituents. So, it is evident the cell wall decrease and digestibility increase on roughage that have high NDF levels and low digestibility.

On grasses and their by-product the ammonization, it has a remarkable effect, especially regarding the digestibility increase whereas in legumes this effect is not observed. This is due the fact that most links found on grasses are ester while other plants present most ether-type links. Ammonia, due its ability of break ester-type links will present better results on grasses or their residues, like demonstrated in the work leaded by Pires et al. (2004) who ammonized sugar cane bagasse and noticed variations on digestibility around $32.1 \%$ for bagasse without treatment and $59.8 \%$ for bagasse treated with $4 \%$ of $\mathrm{NH}_{3}$.

The nitrogen source that will be used is another factor that reflects ammonization efficiency. $\mathrm{NH}_{3}$ has shown to be more efficient than urea both for maintenance and improvement of nutritive value. However, its acquisition is harder when compared to urea. But when urea is used, moisture content, treatment period, ambient temperature and urease presence must be considered. So, the success of roughages treatment with urea as ammonia source depends on a fast hydrolysis followed by the ammonia contact with forages, which is dependent of moisture content in the material that will be treated and the presence of active urease. Urea is broken for ammonia production and sometimes the addition of some urease and water sources is necessary. Ideal moisture for the treatment with urea of low quality forages ranges from 30 to 50\% (Dolberg, 1992; Sarmento et al., 2001).

Reis et al. (1997) using $\mathrm{NH}_{3}$ (0.5 and 1.0\% DM base) and urea (0.9 and 1.8\% DM base) for the treatment of Cynodon dactylon hay with high moisture and ammonized during 65 days, noticed an increase on in vitro digestibility of dry matter while for no-treated hay (moisture of $12-15 \%$ ) IVDMD was $46.5 \%$ and for treated hay (moisture of 20-25\%) with $\mathrm{NH}_{3}(0.5$ and $1 \%$ ) and urea ( 0.9 and $1.8 \%$ ), the values founded were 59.0, 56.3, 51.4 and $51.1 \%$ respectively, showing a better $\mathrm{NH}_{3}$ efficiency when compared to urea.

The attention for the treatment with $\mathrm{NH}_{3}$ or urea is due the great potential that both have to improve the nutritive value of roughages since they act over the fibrous part breaking the chemical bands between lignin and hemicellulose. In addition to hemicellulose solubilization, there's a partial break in celluloses structure due the break of hydrogen bands. According to Garcia \& Pires (1998), all these reactions occur due a fiber expansion and they facilitate the access of cellulase enzyme to substrate, improving the digestion process. For $\mathrm{NH}_{3}$ use in roughages treatment, Garcia \& Pires (1998) highlighted that there is an increase in the crude protein content in forages (two or three times), in digestibility (8 to 12 percentage units), in consume (average of 20\%) and also in fungus control.

Ammonization (using $\mathrm{NH}_{3}$ or urea) promotes an improvement of nutritive value in different roughages, increasing levels in CP values and decreasing NDF values (Table 2) and also promotes the increasing of in vitro dry matter digestibility (IVDMD) (Table 3).

In a work made by Carvalho et al. (2006), the authors evaluated urea dosages in the treatment of sugar cane bagasse and verified an increase on CP content, 3.7, 6.9, 9.9 and $12.9 \%$ and a decrease on NDF content, 78.1, 71.3, 64.4 and 57.6, respectively, for urea doses (\%DM) of 0, 2.5, 5.0 and $7.5 \%$. For IVDMD, the authors correlated treatments without addition of urea and with the addition of $7.5 \%$, and they noticed an increase of 15.9 percentage units for treated bagasse. Pires et al. (2004), also testing the viability of using chemical products in roughages that present poor quality among other treatments, applied $4 \%$ of $\mathrm{NH}_{3}$ on sugar cane bagasse and verified an increase on material's IVDMD, 32.1 and 59.8\% for treatments without $\mathrm{NH}_{3}$ and with an addition of $4 \%$.

According to Reis et al. (2002), the annual crop residues from summer and winter, which are hays or grass silage harvested in advanced development stage from the harvest 
Table 2 - Crude protein content (CP) and neutral detergent fiber (NDF) of roughages treated with different doses of anhydrous ammonia $\left(\mathrm{NH}_{3}\right)$ and urea

\begin{tabular}{|c|c|c|c|c|}
\hline Roughage & Treatment & CP (\%) & NDF (\%) & Author \\
\hline Sugar cane bagasse ${ }^{1}$ & $\begin{array}{l}\text { Control } \\
4 \% \mathrm{NH}_{3}\end{array}$ & $\begin{array}{c}1.8 \\
16.9\end{array}$ & $\begin{array}{l}94.7 \\
75.8\end{array}$ & Pires et al. (2004) \\
\hline Sugar cane bagasse ${ }^{1}$ & $\begin{array}{l}\text { Control } \\
2.5 \% \text { urea } \\
5.0 \% \text { urea } \\
7.5 \% \text { urea }\end{array}$ & $\begin{array}{c}3.7 \\
6.9 \\
9.9 \\
12.9\end{array}$ & $\begin{array}{l}78.1 \\
71.3 \\
64.4 \\
57.6\end{array}$ & Carvalho et al. (2006) \\
\hline Brachiaria decumbens hay ${ }^{1}$ & $\begin{array}{l}\text { Control } \\
3 \% \mathrm{NH}_{3}\end{array}$ & $\begin{array}{l}2.8 \\
9.7\end{array}$ & $\begin{array}{l}83.9 \\
79.4\end{array}$ & Fernandes et al. (2002) \\
\hline $\begin{array}{l}\text { Brachiaria brizantha }{ }^{1} \text { hay with } \\
15 \% \text { of moisture }\end{array}$ & $\begin{array}{l}\text { Control } \\
5 \% \text { urea }\end{array}$ & $\begin{array}{c}3.1 \\
16.3\end{array}$ & $\begin{array}{l}77.5 \\
69.8\end{array}$ & Bertipaglia et al. (2005) \\
\hline $\begin{array}{l}\text { Brachiaria brizantha }{ }^{1} \text { hay } \\
\text { with } 30 \% \text { of moisture }\end{array}$ & $\begin{array}{l}\text { Control } \\
5 \% \text { urea }\end{array}$ & $\begin{array}{c}3.4 \\
12.6\end{array}$ & $\begin{array}{l}78.8 \\
72.0\end{array}$ & \\
\hline Rice straw $^{1}$ & $\begin{array}{l}\text { Control } \\
3 \% \mathrm{NH}_{3}\end{array}$ & $\begin{array}{c}7.2 \\
15.5\end{array}$ & $\begin{array}{l}77.3 \\
74.0\end{array}$ & Cardoso et al. (2004) \\
\hline Rice straw $^{1}$ & $\begin{array}{l}2 \% \text { urea } \\
4 \% \text { urea } \\
6 \% \text { urea }\end{array}$ & $\begin{array}{l}10.2 \\
15.3 \\
19.8\end{array}$ & $\begin{array}{l}77.0 \\
76.0 \\
75.0\end{array}$ & Fadel et al. (2003) \\
\hline Corn fodder ${ }^{1}$ & $\begin{array}{c}\text { Control } \\
2,4 \% \mathrm{NH}_{3}\end{array}$ & $\begin{array}{c}5.2 \\
10.6\end{array}$ & - & Neiva et al. (1998b) \\
\hline
\end{tabular}

${ }^{1}$ Dose applied in percentage of dry matter.

Table 3 - In vitro dry matter digestibility (IVDMD) of roughages treated with different doses of anhydrous ammonia $\left(\mathrm{NH}_{3}\right)$ and urea

\begin{tabular}{|c|c|c|c|}
\hline Roughage & Treatment & IVDMD (\%) & Author \\
\hline Sugar cane bagasse ${ }^{1}$ & $\begin{array}{l}\text { Control } \\
4 \% \mathrm{NH}_{3}\end{array}$ & $\begin{array}{l}32.1 \\
59.8\end{array}$ & Pires et al. (2004) \\
\hline Sugar cane bagasse ${ }^{1}$ & \begin{tabular}{ll}
\multicolumn{2}{c}{ Control } \\
$2.5 \%$ & urea \\
$5.0 \%$ & urea \\
$7.5 \%$ & urea
\end{tabular} & $\begin{array}{l}32.9 \\
38.2 \\
43.5 \\
48.8\end{array}$ & Carvalho et al. (2006) \\
\hline Brachiaria brizantha hay ${ }^{1}$ & $\begin{array}{c}\text { Control } \\
3 \% \mathrm{NH}_{3} \\
3 \% \text { urea } \\
5 \% \text { urea }\end{array}$ & $\begin{array}{l}34.3 \\
52.9 \\
35.7 \\
39.9\end{array}$ & Pires et al. (2006b) \\
\hline Brachiaria decumbens hay ${ }^{1}$ & $\begin{array}{c}\text { Control } \\
3 \% \mathrm{NH}_{3}\end{array}$ & $\begin{array}{l}47.5 \\
59.6\end{array}$ & Fernandes et al. (2002) \\
\hline Brachiaria brizantha ${ }^{1}$ hay with $15 \%$ of moisture & $\begin{array}{l}\text { Control } \\
5 \% \text { urea }\end{array}$ & $\begin{array}{l}53.6 \\
65.1\end{array}$ & Bertipaglia et al. (2005) \\
\hline Brachiaria brizantha ${ }^{1}$ hay with $30 \%$ of moisture & $\begin{array}{l}\text { Control } \\
5 \% \text { urea }\end{array}$ & $\begin{array}{l}56.3 \\
66.5\end{array}$ & \\
\hline Rice straw ${ }^{1}$ & $\begin{array}{c}\text { Control } \\
3 \% \mathrm{NH}_{3}\end{array}$ & $\begin{array}{l}43.0 \\
59.0\end{array}$ & Cardoso et al. (2004) \\
\hline Sorghum silage $(\mathrm{BR} 601)^{2}$ & $\begin{array}{l}\text { Control } \\
0.5 \% \text { urea }\end{array}$ & $\begin{array}{l}61.1 \\
60.4\end{array}$ & Vieira et al. (2004) \\
\hline
\end{tabular}

${ }_{1}^{1}$ Dose applied in dry in percentage of dry matter.

2 Dose applied in percentage of natural matter (sorghum with $30.1 \%$ of DM). 
of tropical forage grass seeds by the scanning method, are also other forage options for ruminants feeding, however they present a poor nutritive value.

On Table 2 is presented some results where were doses of $\mathrm{NH}_{3}$ or urea were applied on Brachiaria hays and on rice straws. It is noticed an increase on CP contents and a decrease of NDF in all works showing that such chemical additives are effective to improve the nutritive level of these roughages. This efficiency can be even more ratified by IVDMD values showed at Table 3, which meaningfully increase for treated materials.

Pires et al. (2006b), when they made the treatment of Brachiaria brizantha hay with $\mathrm{NH}_{3}$ and urea doses, noticed that $\mathrm{NH}_{3}$ was more efficient in increase material's IVDMD. Hay IVDMD values were 34.3, 52.9, 35.7 and 39.9\%, respectively, for control with $3 \%$ of $\mathrm{NH}_{3}, 3$ and $5 \%$ of urea, treatments. The greater efficiency of $\mathrm{NH}_{3}$ regarding urea has been frequently discussed in research works. For urea application, the presence of urease enzyme and moisture are essential for the urea breaking and release of ammonia. As $\mathrm{NH}_{3}$ is already find under gas form and is readily available to be used, it acts in a most efficient form over fibrous compounds promoting higher IVDMD values in roughage.

It is noticed that some factors as ambient temperature, forages' moisture content, quantity of ammonia or urea added, treatment period and roughage chemical characteristics should never left out because they directly affect the treatment's efficiency.

As reported, rice and wheat straws, and other annual crops can be used for animal's feeding. The nutritive value of rice straw was studied by Cardoso et al. (2004), who noticed a IVDMD increase using $3 \%$ of $\mathrm{NH}_{3}(\% \mathrm{DM})$. The authors noticed values of, respectively, 43.0 and $59.0 \%$ of IVDMD for $\mathrm{NH}_{3}$ doses of 0 and 3\%.

$\mathrm{NH}_{3}$ and urea on silages were also been successfully used. Recent works show the increase of CP contents and the decrease of NDF on silages treated with these chemical compounds.

Fernandes et al. (2009), when applied urea during sorghum ensilage noticed values of 7.9, 15.9, 23.8 and 31.8\% for CP and 64.4, 61.1, 60.3 and 59.3\% for NDF, respectively, for urea doses of 0, 2.5, 5.0 and 7.5\% (Table 4).

The digestibility both in vitro and in vivo increases with the addition of $\mathrm{NH}_{3}$ or urea. The benefits observed on digestibility of these materials are directly related with the fiber's reduction and expansion, once that such products cause a softening in cell wall compounds in treated forages allowing a more pronounced action of microbial enzymes existent in rumen (Garcia \& Pires, 1998).

The NDF digestibility in goats fed Brachiaria decumbens hay treated with $\mathrm{NH}_{3}$ or urea increased with

Table 4 - Crude protein contents (CP) and neutral detergent fiber of silages treated with different doses of urea and anhydrous ammonia $\left(\mathrm{NH}_{3}\right)$

\begin{tabular}{|c|c|c|c|c|}
\hline Roughage & Treatment & CP (\%) & NDF (\%) & Author \\
\hline Sugar cane silage ${ }^{1}$ & $\begin{array}{l}\text { Control } \\
0.5 \% \text { urea }\end{array}$ & $\begin{array}{l}3.0 \\
8.4\end{array}$ & $\begin{array}{l}69.6 \\
66.3\end{array}$ & Ferreira et al. (2007) \\
\hline Sugar cane silage ${ }^{2}$ & $\begin{array}{l}\text { Control } \\
1.0 \% \text { urea }\end{array}$ & $\begin{array}{c}4.4 \\
10.5\end{array}$ & $\begin{array}{l}70.4 \\
69.7\end{array}$ & Santos et al. (2004) \\
\hline Sorghum silage ${ }^{3}$ & $\begin{array}{l}\text { Control } \\
2.5 \% \text { urea } \\
5.0 \% \text { urea } \\
7.5 \% \text { urea }\end{array}$ & $\begin{array}{c}7.9 \\
15.9 \\
23.8 \\
31.8\end{array}$ & $\begin{array}{l}64.4 \\
61.0 \\
60.3 \\
59.3\end{array}$ & Fernandes et al. (2009) \\
\hline Sorghum silage $\mathrm{e}^{4}$ & $\begin{array}{c}\text { Control } \\
2.5 \% \mathrm{NH}_{3}\end{array}$ & $\begin{array}{c}8.1 \\
18.3\end{array}$ & $\begin{array}{l}66.9 \\
62.8\end{array}$ & Pires et al. (2003) \\
\hline Pennisetum purpureum silage ${ }^{5}$ & $\begin{array}{c}\text { Control } \\
0.5 \% \text { urea }\end{array}$ & $\begin{array}{l}6.2 \\
9.2\end{array}$ & - & Andrade \& Melotti (2004) \\
\hline Corn silage ${ }^{4}$ & $\begin{array}{c}\text { Control } \\
1.2 \% \mathrm{NH}_{3}\end{array}$ & $\begin{array}{c}7.4 \\
12.5\end{array}$ & - & Neiva et al. (1998a) \\
\hline
\end{tabular}

\footnotetext{
${ }^{1}$ Dose applied in percentage of natural matter (NM) (sugar cane with $28 \%$ of dry matter [DM])

2 Dose applied in percentage of NM (authors did not mention the sugar cane DM content).

3 Dose applied in percentage of NM (sorghum with $30.1 \%$ of DM).

${ }^{4}$ Dose applied in percentage of DM.

${ }^{5}$ Dose applied in percentage of NM (Pennisetum purpureum with $15.3 \%$ of DM).

${ }^{6}$ Dose applied in percentage of NM (authors did not mention the sunflower DM value).
} 
the addition of those products (Rosa et al., 1998), and it was observed that the benefits of $\mathrm{NH}_{3}$ and urea were similar and also that treated hays presented higher digestibility than not treated hays (Table 5). The digestibility values observed by authors were 60.1, 70.7, 69.6, 67.4 and $68.3 \%$, respectively, for $\mathrm{NH}_{3}$ doses of 0.2 and $3 \%$ and urea doses of 3.6 and $6.4 \%$.

According to Neiva et al. (1998b), the benefits of chemical treatment of forages are relevant. The authors verified a increase of 10 percentage units to NDF digestibility in bovine fed corn silage with application of $1.2 \%$ of $\mathrm{NH}_{3}$ (\%DM). In the same work, the authors tested the addition of $2.4 \%$ of $\mathrm{NH}_{3}$ to corn fodder and they verified an increase of $11.5 \%$. In a work with Pennisetum purpureum silage, Silva et al. (2007) added 5\% of urea (\%DM) during the grass ensilage and noticed an increase in NDF digestibility when they supplied such diet for Santa Inês sheep. It was reported 39.2 and 55.2\% values, respectively, for urea doses of 0 and $5 \%$.

As Rosa et al. (2001) the high digestibility values in forages treated with $\mathrm{NH}_{3}$ or urea comes from the marked changes in chemical composition, especially due the relation of fraction of nitrogen compounds and cell wall.

On Table 6 are shown the consume values for dry matter in \% live weight (LW) and average daily gain (kg/day); these data was collected of works complied from literature of animals fed forage treated with $\mathrm{NH}_{3}$ or urea.

All benefits from chemical treatments previously reported cause a direct effect over animals' intake and weight gain, once that the main purpose of the treatment is to make the roughage more enjoyable through modifications on cell wall, allowing a higher efficiency of microorganisms over substrate. According to Reis et al. (2002), we must take into account that treatment can increase the nutrient content of forage, which will contribute to increase its efficiency of use.

On works made by Pires et al. (2003, 2004), the authors observed a higher consume from animals fed roughages treated with $\mathrm{NH}_{3}$. On this work, among other treatments, it was used sorghum silage treated with $2.5 \%$ of $\mathrm{NH}_{3}$ (\%DM) and sugar cane bagasse treated with $4 \%$ of $\mathrm{NH}_{3}(\% \mathrm{DM})$, respectively (Table 6).

Bovine's intake and weight gain were evaluated by Cardoso et al. (2004), who supplied rice straw treated with $\mathrm{NH}_{3}$ to beef cattle. The authors verified a higher intake and weight gain on animals that received straw treated with 3\% of $\mathrm{NH}_{3}$ (Table 6).

Roughages treated with sodium hydroxide $(\mathrm{NaOH})$ and calcium oxide ( $\mathrm{CaO})$

The roughage is considered as the lowest cost compound in ruminants' diet and its nutritive quality is extremely important and it is inversely related to the need of concentrates on diet. As reported, the forages' seasonality can be alleviated with the use of forage in its maintained form.

Among the roughages for ruminants, sugar cane has been highlighted in Brazil's agribusiness scenario and during the recent years its cultivation has been even more expanding. The high productivity of green mass (80 to $120 \mathrm{t} / \mathrm{ha}$ ), the low cost by dry matter unit, the maintenance of nutritive value for up to six months after maturation and the harvest period coincides with scarcity period of forages in pastures combined with the facility of obtaining

Table 5 - Neutral detergent fiber digestibility (NDFD) of roughages treated with different doses of anhydrous ammonia $\left(\mathrm{NH}_{3}\right)$ and urea

\begin{tabular}{|c|c|c|c|c|}
\hline Roughage & Animal & Treatment & NDFD (\%) & Author \\
\hline Brachiaria decumbens ${ }^{1}$ hay & Goat & $\begin{array}{c}\text { Control } \\
2 \% \mathrm{NH}_{3} \\
3 \% \mathrm{NH}_{3} \\
3.6 \% \text { urea } \\
6.4 \% \text { urea }\end{array}$ & $\begin{array}{l}60.1 \\
70.7 \\
69.6 \\
67.4 \\
68.3\end{array}$ & Rosa et al. (1998) \\
\hline Corn fodder ${ }^{1}$ & Bovine & $\begin{array}{c}\text { Control } \\
2.4 \% \mathrm{NH}_{3}\end{array}$ & $\begin{array}{l}57.4 \\
68.9\end{array}$ & Neiva et al. (1998b) \\
\hline Corn silage $^{1}$ & Bovine & $\begin{array}{c}\text { Control } \\
1.2 \% \mathrm{NH}_{3}\end{array}$ & $\begin{array}{l}52.9 \\
62.9\end{array}$ & \\
\hline Pennisetum purpureum silage ${ }^{1}$ & Sheep & $\begin{array}{l}\text { Control } \\
5 \% \text { urea }\end{array}$ & $\begin{array}{l}39.2 \\
55,2\end{array}$ & Silva et al. (2007) \\
\hline Rice straw $^{1,2}$ & Bovine & $\begin{array}{l}\text { Urea - C1 } \\
\text { Urea - C2 } \\
\text { Urea - C3 } \\
\text { Urea - C4 }\end{array}$ & $\begin{array}{l}60.9 \\
61.8 \\
69.8 \\
65.2\end{array}$ & Fadel et al. (2004) \\
\hline
\end{tabular}

\footnotetext{
${ }^{1}$ Dose applied in percentage of dry matter (DM).
}

${ }^{2} \mathrm{C} 1=$ not treated rice straw + urea $(20 \mathrm{~g} / \mathrm{kg}$ of DM), $\mathrm{C} 2=\mathrm{C} 1+$ concentrate, $\mathrm{C} 3=$ treated straw rice $(4 \%$ of urea $)$ and $\mathrm{C} 4=\mathrm{C} 3+\mathrm{concentrate}$. 
Table 6 - Dry matter intake (DMI), in \% live weight (LW) and average daily gain (ADG) in kg/day of bovine fed roughage treated with different doses of anhydrous ammonia $\left(\mathrm{NH}_{3}\right)$ and urea

\begin{tabular}{|c|c|c|c|c|}
\hline Roughage & Treatment & DMI (\%LW) & ADG (kg/dia) & Author \\
\hline Rice straw ${ }^{1}$ & $\begin{array}{c}\text { Control } \\
3 \% \mathrm{NH}_{3}\end{array}$ & $\begin{array}{l}1.8 \\
2.0\end{array}$ & $\begin{array}{l}1.25 \\
1.59\end{array}$ & Cardoso et al. (2004) \\
\hline Sorghum silage ${ }^{1}$ & $\begin{array}{c}\text { Control } \\
2.5 \% \mathrm{NH}_{3}\end{array}$ & $\begin{array}{l}2.5 \\
2.7\end{array}$ & $\begin{array}{l}- \\
-\end{array}$ & Pires et al. (2003) \\
\hline Sugar cane bagasse ${ }^{1}$ & $\begin{array}{l}\text { Control } \\
4 \% \mathrm{NH}_{3}\end{array}$ & $\begin{array}{l}1.9 \\
2.5\end{array}$ & $\begin{array}{l}0.70 \\
1.03\end{array}$ & Pires et al. (2004) \\
\hline Brachiaria decumbens hay & $\begin{array}{l}\text { Control } \\
3 \% \mathrm{NH}_{3} \\
5 \% \text { urea }\end{array}$ & $\begin{array}{l}2.0 \\
2.2 \\
1.9\end{array}$ & $\begin{array}{l}0.60 \\
0.53 \\
0.37\end{array}$ & Fernandes et al. (2002) \\
\hline
\end{tabular}

${ }^{1}$ Dose applied in percentage of dry matter.

seedlings and planting and the possibility of reach reasonable weight gain rates has attracted ranchers to use sugar cane as a source of roughage food for bovine feeding.

The great adoption of sugar cane as a supplementary roughage for dry periods is based in its ease of culture and tradition, in its use under fresh form through daily cuts, and it is traditionally well-known by produces. This daily manpower is always questioned by producers, mainly large, which feed large herds.

However, despite the widespread use of sugar cane, constant reports on literature indicate that it has a low digestibility that causes direct implications on nutrients intake by animals, resulting in a low productivity of animals during dry season (Vilela et al., 2007), which is a period that animals most need this roughage. Due such reasons, the search for a solution to improve this roughage's quality and, consequently, the animals' performance has been intensified during the last years.

Although $\mathrm{NaOH}$ has been studied as additive for straws and hays with poor quality during the last decades, nowadays we can notice that sugar cane is the forage that has received more attention of researches when the objective is $\mathrm{NaOH}$ treatment (Pires et al., 2006a; Freitas et al., 2006; Ribeiro et al., 2009).

Another additive that has been largely used for sugar cane treatment is $\mathrm{CaO}$, which has been applied in sugar cane during its several processing forms. The $\mathrm{CaO}$ indicated for use in roughages' treatment is microprocessed or micropulverized lime, which is a product with mineral origin that passes through an industrial process and acquires an appearance of fine material (Martines, 2006).

We can notice the use of additives during sugar cane silage. The loss from sugars reduction during sugar cane silage can reach $30 \%$ with a consequent production of ethanol, due this fact that the additive is used during ensilage.
During the last years, the use of $\mathrm{NaOH}$ and $\mathrm{CaO}$ additives has been directed for sugar cane treatment. So, the chemical treatment using alkaline additives to improve the quality of forages is an interesting alternative to potentiate the use of these foods by ruminants.

The addition of $\mathrm{NaOH}$ or $\mathrm{CaO}$ in roughages, different from $\mathrm{NH}_{3}$ and urea chemical compounds, does not cause alterations in nitrogen compounds. This is because its own composition does not contain any nitrogen element. Tables 7, 8 and 9 can be verified CP contents of roughages treated, respectively, with $\mathrm{NaOH}$ and $\mathrm{CaO}$.

For NDF contents, the addition of $\mathrm{NaOH}$ causes meaningful reductions in these fractions; this is also observed in works employing the addition of $\mathrm{CaO}$. Evaluating the addition of $\mathrm{NaOH}$ or $\mathrm{CaO}$ doses of $0,0.75,1.5$ and 2.25 to sugar cane, Ribeiro et al. (2007) noticed reductions on NDF contents, verifying NDF values of 59.4, 56.3, 50.2 and 46.4\%, and 58.9, 56.6, 51.8 and 47.9\%, respectively, for $\mathrm{NaOH}$ and $\mathrm{CaO}$ applications. Similar results were also obtained by Siqueira et al (2007), which are related to $\mathrm{NaOH}$ dose of $1 \%$ during sugar cane silage. They verified decreasing of 16 percentage units in NDF contents in comparison to not treated silage. In a work leaded by Lopes et al. (2007), the authors assessed the use of $\mathrm{NaOH}$ in Pennisetum purpureum and the results were below the values observed for sugar cane, as can be verified in the works of Freitas et al. (2006) and Pedroso et al. (2007) (Table 7).

Sugar cane, under different processing forms was studied by Ezequiel et al. (2005). The authors tested sugar cane in natura cut and supplied on time, sugar cane hydrolyzed with $\mathrm{NaOH}$ during 24 hours, hay hydrolyzed sugar cane and silage hydrolyzed sugar cane, and in all treatments was used $1.5 \%$ of $\mathrm{NaOH}$ applied at $\mathrm{NM}$ base. As already verified in other works, CP contents did not present great variations, NDF contents decreased, and IVDMD 
Table 7 - Crude protein (CP) contents and neutral detergent fiber (NDF) of roughages treated with sodium hydroxide (NaOH)

\begin{tabular}{|c|c|c|c|c|}
\hline Roughage & Treatment & CP (\%) & NDF (\%) & Author \\
\hline Sugar cane ${ }^{1}$ & $\begin{array}{c}\text { Control } \\
0.75 \% \mathrm{NaOH} \\
1.5 \% \mathrm{NaOH} \\
2.25 \% \mathrm{NaOH}\end{array}$ & $\begin{array}{l}- \\
- \\
-\end{array}$ & $\begin{array}{l}59.4 \\
56.3 \\
50.2 \\
46.4\end{array}$ & Ribeiro et al. (2007) \\
\hline Sugar cane silage ${ }^{1}$ & $\begin{array}{c}\text { Control } \\
1.0 \% \mathrm{NaOH}\end{array}$ & $\begin{array}{l}1.7 \\
2.0\end{array}$ & $\begin{array}{l}75.3 \\
59.2\end{array}$ & Siqueira et al. (2007) \\
\hline Sugar cane silage ${ }^{2}$ & \begin{tabular}{ll}
\multicolumn{2}{c}{ Control } \\
$1.0 \%$ & $\mathrm{NaOH}$ \\
$2.0 \%$ & $\mathrm{NaOH}$ \\
$3.0 \%$ & $\mathrm{NaOH}$
\end{tabular} & $\begin{array}{l}4.4 \\
3.9 \\
2.9 \\
2.8\end{array}$ & $\begin{array}{l}64.5 \\
55.4 \\
47.3 \\
44.8\end{array}$ & Pedroso et al. (2007) \\
\hline Sugar cane silage ${ }^{1}$ & $\begin{array}{c}\text { Control } \\
3.0 \% \mathrm{NaOH}\end{array}$ & $\begin{array}{l}3.9 \\
3.4\end{array}$ & $\begin{array}{l}61.2 \\
50.4\end{array}$ & Freitas et al. (2006) \\
\hline Sugar cane bagasse ${ }^{1}$ & 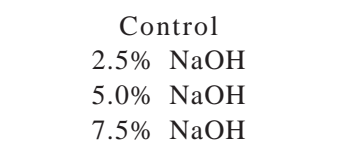 & $\begin{array}{l}- \\
- \\
- \\
-\end{array}$ & $\begin{array}{l}97.4 \\
94.6 \\
91.7 \\
88.8\end{array}$ & Pires et al. (2006a) \\
\hline Pennisetum purpureum ${ }^{1}$ & $\begin{array}{c}\text { Control } \\
3 \% \mathrm{NaOH} \\
1.5 \% \mathrm{NaOH}+1.5 \% \mathrm{CaO}\end{array}$ & $\begin{array}{l}- \\
- \\
-\end{array}$ & $\begin{array}{l}84.8 \\
80.2 \\
80.1\end{array}$ & Lopes et al. (2007) \\
\hline
\end{tabular}

${ }_{1}^{1}$ Dose applied in percentage of natural matter.

${ }^{2}$ Dose applied in percentage of dry matter.

Table 8 - Crude protein (CP) contents and neutral detergent fiber (NDF) of roughages treated with calcium oxide (CaO)

\begin{tabular}{|c|c|c|c|c|}
\hline Roughage & Treatment & СР (\%) & NDF (\%) & Author \\
\hline Sugar cane ${ }^{1}$ & $\begin{array}{c}\text { Control } \\
0.75 \% \mathrm{CaO} \\
1.5 \% \mathrm{CaO} \\
2.25 \% \mathrm{CaO}\end{array}$ & $\begin{array}{l}- \\
- \\
- \\
-\end{array}$ & $\begin{array}{l}58.9 \\
56.6 \\
51.8 \\
47.9\end{array}$ & Ribeiro et al. (2007) \\
\hline Sugar cane ${ }^{1}$ & $\begin{array}{c}\text { Control } \\
0.5 \% \mathrm{CaO} \\
0.6 \% \mathrm{CaO}\end{array}$ & $\begin{array}{l}- \\
- \\
-\end{array}$ & $\begin{array}{l}41.2 \\
40.7 \\
41.3\end{array}$ & Oliveira et al. (2007) \\
\hline Sugar cane ${ }^{1}$ & $\begin{array}{c}\text { Control } \\
0.5 \% \mathrm{CaO} \\
0.5 \% \mathrm{Ca}(\mathrm{OH})_{2}\end{array}$ & $\begin{array}{l}2.7 \\
2.5 \\
2.5\end{array}$ & $\begin{array}{l}45.3 \\
41.1 \\
40.1\end{array}$ & Mota et al. (2007) \\
\hline Sugar cane $^{1}$ & $\begin{array}{l}\text { Control } \\
0.5 \% \mathrm{CaO} \\
1.0 \% \mathrm{CaO} \\
1.5 \% \mathrm{CaO}\end{array}$ & $\begin{array}{l}- \\
- \\
- \\
-\end{array}$ & $\begin{array}{l}42.1 \\
41.0 \\
35.4 \\
34.5\end{array}$ & Teixeira Júnior et al. (2007) \\
\hline Sugar cane silage ${ }^{1}$ & $\begin{array}{c}\text { Control } \\
0.5 \% \mathrm{CaO} \\
1.0 \% \mathrm{CaO} \\
2.0 \% \mathrm{CaO}\end{array}$ & $\begin{array}{l}3.2 \\
3.3 \\
3.1 \\
3.2\end{array}$ & $\begin{array}{l}63.3 \\
60.4 \\
58.5 \\
49.5\end{array}$ & Balieiro Neto et al. (2007) \\
\hline Sugar cane silage ${ }^{1}$ & $\begin{array}{c}\text { Control } \\
0.5 \% \mathrm{CaO} \\
1.0 \% \mathrm{CaO} \\
1.5 \% \mathrm{CaO} \\
2.0 \% \mathrm{CaO}\end{array}$ & $\begin{array}{l}2.8 \\
2.3 \\
2.3 \\
2.4 \\
2.0\end{array}$ & $\begin{array}{l}62.9 \\
46.5 \\
43.7 \\
41.2 \\
37.9\end{array}$ & Cavali (2006) \\
\hline Sugar cane silage ${ }^{1}$ & $\begin{array}{l}\text { Control } \\
1 \% \mathrm{CaO}\end{array}$ & $\begin{array}{l}- \\
-\end{array}$ & $\begin{array}{l}69.0 \\
47.2\end{array}$ & Roth et al. (2007) \\
\hline
\end{tabular}

\footnotetext{
${ }^{1}$ Dose applied in percentage of natural matter.
} 
Table 9 - Crude protein (CP) contents and neutral detergent fiber (NDF), in vitro dry matter digestibility (IVDMD) and dry matter intake (DMI) in \% weight live (WL) of steers fed sugar cane treated with sodium hydroxide processed in different forms

\begin{tabular}{|c|c|c|c|c|}
\hline Treatment & CP (\%) & NDF (\%) & IVDMD (\%) & DMI (\%PV) \\
\hline Sugar cane in natura & 3.0 & 55.6 & 58.6 & 1.2 \\
\hline Hydrolyzed sugar cane ${ }^{1}$ & 2.5 & 47.3 & 80.2 & 1.5 \\
\hline Hay hydrolyzed sugar cane 1 & 2.0 & 43.0 & 75.4 & 1.4 \\
\hline Silage hydrolyzed sugar cane ${ }^{1}$ & 1.6 & 43.2 & 72.5 & 1.2 \\
\hline
\end{tabular}

$1.5 \%$ of $\mathrm{NaOH}$ in $\%$ of natural matter (Ezequiel et al., 2005).

increased with $\mathrm{NaOH}$ addition. According to the presented results, it appears that hydrolyzed sugar cane by $24 \mathrm{~h}$ and hay hydrolyzed sugar cane presents best results, once that such treatment allowed a large DM intake (Table 9).

For IVDMD values of materials treated with $\mathrm{NaOH}$, it is noticed that in every situation there is an increase. According to the results presented on Table 10, everything indicates that the application of 1 to $2 \%$ of $\mathrm{NaOH}$ is enough to promote good results in IVDMD.

In sugar cane works, we can observe that the addition of $\mathrm{CaO}$ is made both for disintegrated sugar cane resting for 24 hours as during ensilage. The reduction of NDF contents is noticed in both ways of using sugar cane, demonstrating that $\mathrm{CaO}$ is a hydrolyzing additive with potential action in different environments.

One factor that may affect sugar cane hydrolysis is the treatment period. According to Martinez (2006), sugar cane must be submitted to a period of at least 3 to 24 hours in order that hydrolysis occurs in an efficient way.

Besides, another important factor is material's moisture, which is necessary for calcium hydroxide formation. As Moraes (2006), it is necessary $1.0 \mathrm{~mol}$ of $\mathrm{H}_{2} \mathrm{O}$ for each $\mathrm{CaO}$ mol to calcium hydroxide formation $\left(\mathrm{Ca}(\mathrm{OH})_{2}\right)$; in other words, for each $56.0 \mathrm{~g}$ of lime is necessary $18.0 \mathrm{~g}$ of water.
Cavali (2006) evaluated $\mathrm{CaO}$ doses of 0, 0.5, 1.0, 1.5 and $2.0 \%$ of $\mathrm{CaO}$ during sugar cane ensilage and verified a reduction in NDF contents and an increase of IVDMD. According the results presented by the author, IVDMD increased 35.5, 54.8, 61.6 and $68.4 \%$, respectivelly for treatments, and $0.5,1.0,1.5$ and 2,0\% regarding control treatment without $\mathrm{CaO}$ addition.

In a work made by Balieiro Neto et al. (2007), the authors also verified expressive increases on IVDMD with the addition of $\mathrm{CaO}$ during sugar cane ensilage (Table 11). The IVDMD increase, which was noticed by these authors demonstrated $\mathrm{CaO}$ efficiency as additive reducing the constituents of roughages' cell wall and improving digestibility.

Ribeiro et al. (2007) noticed a reduction in lignin contents when they hydrolyzed sugar cane with $\mathrm{CaO}$ doses of $0,0.75,1.5$ and $2.25 \%$ (\%NM) stored during 24 hours. In the same way, Balieiro Neto et al. (2007) also noticed a lignin reduction with $\mathrm{CaO}$ application. The authors noticed such difference from $\mathrm{CaO}$ doses of $2 \%$ (\%NM). Lignin is a compound that is negatively correlated with digestibility, so the reduction of such compound on materials treated with $\mathrm{CaO}$ may reinforce the IVDMD increase in the works that were previously mentioned.

Table 10 - In vitro dry matter digestibility of (IVDMD) of roughages treated with sodium hydroxide (NaOH)

\begin{tabular}{|c|c|c|c|}
\hline Roughage & Treatment & IVDMD (\%) & Author \\
\hline Sugar cane silage ${ }^{1}$ & $\begin{array}{c}\text { Control } \\
1.0 \% \mathrm{NaOH}\end{array}$ & $\begin{array}{l}35.1 \\
59.6\end{array}$ & Siqueira et al. (2007) \\
\hline Sugar cane silage ${ }^{2}$ & \begin{tabular}{c}
\multicolumn{2}{c}{ Control } \\
$1.0 \% \mathrm{NaOH}$ \\
$2.0 \% \mathrm{NaOH}$ \\
$3.0 \% \mathrm{NaOH}$
\end{tabular} & $\begin{array}{l}45.4 \\
54.8 \\
65.4 \\
67.3\end{array}$ & Pedroso et al. (2007) \\
\hline Sugar cane silage ${ }^{1}$ & $\begin{array}{c}\text { Control } \\
3.0 \% \mathrm{NaOH}\end{array}$ & $\begin{array}{l}59.1 \\
68.0\end{array}$ & Freitas et al. (2006) \\
\hline Sugar cane bagasse ${ }^{1}$ & \begin{tabular}{cc}
\multicolumn{2}{c}{ Control } \\
$2.5 \% \mathrm{NaOH}$ \\
$5.0 \% \mathrm{NaOH}$ \\
$7.5 \% \mathrm{NaOH}$
\end{tabular} & $\begin{array}{l}25.6 \\
29.4 \\
34.5 \\
40.8\end{array}$ & Pires et al. (2006a) \\
\hline
\end{tabular}

${ }_{1}^{1}$ Dose applied in percentage of natural matter.

2 Dose in percentage of dry matter. 
Just some works have evaluated the use viability of sugar cane treated with $\mathrm{CaO}$ in ruminants feeding. So, until now it is hard to affirm that sugar cane treated with $\mathrm{CaO}$ does not affect the animal perfomance (intake, weight gain and milk production).

Carvalho (2008) gave diets with sugar cane treated with $\mathrm{CaO}$ doses of 0, 0.75, 1.5 and 2.5 (\%NM) to lactating cows and did not verify a difference for milk production (Figure 1), recording productive averages around 8.0, 7.7, 7.8 and $7.3 \mathrm{~kg}$ of milk/animal/day, respectively.

More studies are necessary to reach a definitive conclusion regarding the use of $\mathrm{CaO}$ in sugar cane hydrolysis.

On Table 12 are shown averages of dry matter intake and average daily gain of bovine, sheep and goats fed sugar cane treated with $\mathrm{CaO}$.

The results still show a data inconsistence once that present results with worst performance and results with better performance when sugar cane is treated with $\mathrm{CaO}$.

In a work leaded by Moraes (2006), it was verified less intake and less weight gain in heifers fed sugar cane treated

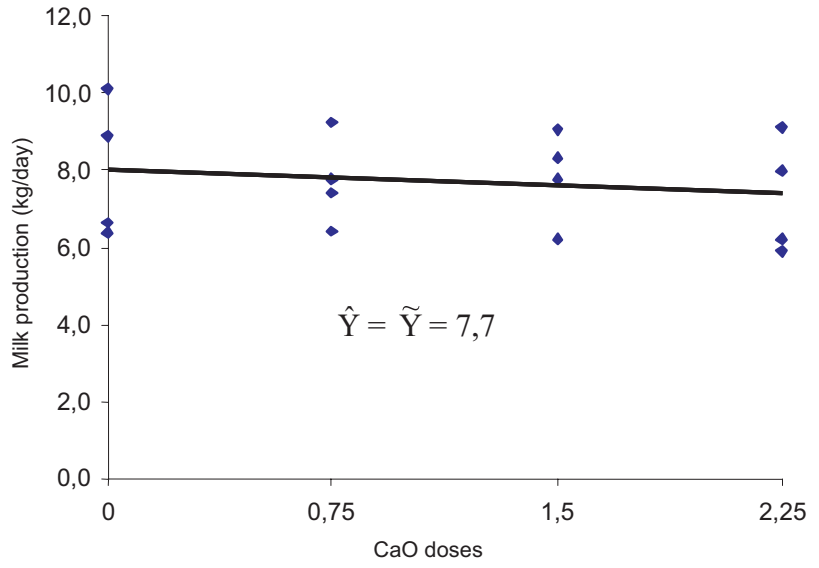

Figure 1 - Milk production (kg/day) of cows fed hydrolyzed sugar cane with different calcium oxide $(\mathrm{CaO})$ doses.

with $\mathrm{CaO} 1 \%(\% \mathrm{NM})$. Among the reasons for which the author tryed to explain such result, the low palatibility of treated material was mentioned with more emphasis. In other work using animals, Pancoti et al. (2007) tested 0.6\% of $\mathrm{CaO}(\% \mathrm{NM})$ in sugar cane treatment and noticed less dry

Table 11 - In vitro dry matter digestibility of (IVDMD) of roughages treated with calcium sodium (CaO)

\begin{tabular}{lccc}
\hline Roughage & Treatment & IVDMD (\%) & Author \\
\hline Sugar cane silage $^{1}$ & Control & 62.1 & Balieiro Neto et al. (2007) \\
& $0.5 \% \mathrm{CaO}$ & 65.6 & 70.7 \\
& $1.0 \% \mathrm{CaO}$ & 79.2 & \\
& $2.0 \% \mathrm{CaO}$ & 48.4 & 65.6 \\
Sugar cane silage $^{1}$ & $\mathrm{Control}$ & 74.9 & 78.2 \\
& $0.5 \% \mathrm{CaO}$ & 81.5 & \\
& $1.0 \% \mathrm{CaO}$ & $2006)$ \\
& $1.5 \% \mathrm{CaO}$ & $\mathrm{CaO}$ & \\
\hline
\end{tabular}

${ }^{1}$ Dose applied in percentage of natural matter.

Table 12 - Dry matter intake (DMI) in \% weight live (WL), and average daily gain (ADG) of roughages treated with different calcium oxide $(\mathrm{CaO})$ doses

\begin{tabular}{|c|c|c|c|c|c|}
\hline Roughage & Animal & Treatment & DMI (\%WL) & ADG (g/day) & Author \\
\hline Sugar cane ${ }^{1}$ & Bovine & $\begin{array}{l}\text { Control } \\
1 \% \mathrm{CaO}\end{array}$ & $\begin{array}{l}1.97 \\
1.72\end{array}$ & $\begin{array}{l}438.98 \\
308.05\end{array}$ & Moraes et al. (2008) \\
\hline Sugar cane $^{1}$ & Ovine & $\begin{array}{c}\text { Control } \\
0.6 \% \mathrm{CaO}\end{array}$ & $\begin{array}{l}2.6 \\
1.6\end{array}$ & - & Pancoti et al. (2007) \\
\hline Sugar cane ${ }^{1}$ & Ovine & $\begin{array}{c}\text { Control } \\
0.75 \% \mathrm{CaO} \\
1.5 \% \mathrm{CaO} \\
2.25 \% \mathrm{CaO}\end{array}$ & $\begin{array}{l}3.39 \\
3.64 \\
3.94 \\
3.99\end{array}$ & $\begin{array}{l}- \\
- \\
-\end{array}$ & Carvalho (2008) \\
\hline Sugar cane ${ }^{1}$ & Goat & $\begin{array}{c}\text { Control } \\
0.75 \% \mathrm{CaO} \\
1.5 \% \mathrm{CaO} \\
2.25 \% \mathrm{CaO}\end{array}$ & $\begin{array}{l}3.20 \\
3.43 \\
3.66 \\
4.09\end{array}$ & $\begin{array}{l}- \\
- \\
-\end{array}$ & Carvalho (2008) \\
\hline
\end{tabular}

\footnotetext{
${ }^{1}$ Dose applied in percentage of natural matter.
} 
matter intake when compared to control treatment. But the data obtained by Carvalho (2008) presented a increase of intake both for ovine and goats (Table 12).

The reasons for a different behavior between chemical analyses and animals performance when those are fed sugar cane treated with $\mathrm{CaO}$ may be due the alterations that occur during the pre-drying method on stove at $60^{\circ} \mathrm{C}$ during 72 hours. This pre-drying temperature can improve $\mathrm{CaO}$ efficiency in cell wall, reducing NDF and improving digestibility, once that the food supplied for ruminants is not submitted to this process. Another factor may be connected to calcium and phosphorus relation when forages are treated with $\mathrm{CaO}$. This relation is increased to an amont that can affect ruminal microorganisms. Therefore, it is necessary to evaluate the calcium and phosphorus levels and to establish a relation of these compounds with ruminant's diet.

\section{Final Considerations}

The use of alkaline products maintains high moisture roughages, and also improves its nutritive value.

Factors as source and dose are responsible for the quality improvement degree of treated roughages.

Urea and anhydrous ammonia need more time to cause the cell wall breaking reaction in treated roughages, but such reactions supply non-proteic nitrogen, which will be used by ruminal bacteria.

Sodium hydroxide and calcium oxide promote an improvement in nutritive value of treated roughages in smaller periods than anhydrous ammonia or urea.

Calcium oxide is less efficient than sodium hydroxide on the improvement of nutritive value of treated roughages, however its handling is easier and less dangerous.

The calcium:phosphorus relation on roughages treated with calcium sodium must be better evaluated in works that also approach the animal performance.

\section{References}

ANDRADE, S.J.T.; MELOTTI, L. Efeito de alguns tratamentos sobre a qualidade da silagem de capim-elefante cultivar Napier (Pennisetum purpureum, Schum.). Brazilian Journal of Veterinary Research and Animal Science, v.41, n.6, p.409415, 2004.

BALIEIRO NETO, G.; SIQUEIRA, G.R.; REIS, R.A. et al. Óxido de cálcio como aditivo na ensilagem de cana-de-açúcar. Revista Brasileira de Zootecnia, v.36, n.5, p.1231-1239, 2007.

BERTIPAGLIA, L.M.A.; LUCA, S.; MELO, G.M.P. et al. Avaliação de fontes de urease na amonização de fenos de Brachiaria brizantha com dois teores de umidade. Revista Brasileira de Zootecnia, v.34, n.2, p.378-386, 2005.
CARDOSO, G.C.; GARCIA, R.; SOUZA, A.L. et al. Desempenho de novilhos Simental alimentados com silagem de sorgo, cana-deaçúcar e palhada de arroz tratada ou não com amônia anidra. Revista Brasileira de Zootecnia, v.33, n.6, p.2132-2139, 2004 (supl. 2).

CARVALHO, G.G.P. Cana-de-açúcar tratada com óxido de cálcio em dietas para ovinos, caprinos, novilhas e vacas em lactação. 2008. 279f. Tese (Doutorado em Zootecnia) Universidade Federal de Viçosa, Viçosa, MG.

CARVALHO, G.G.P.; PIRES, A.J.V.; VELOSO, C.M. et al. Valor nutritivo do bagaço de cana-de-açúcar amonizado com quatro doses de uréia. Pesquisa Agropecuária Brasileira, v.41, n.1, p.125-132, 2006.

CAVALI, J. Cana-de-açúcar ensilada com óxido de cálcio, capim-elefante ou inoculante bacteriano. 2006. $60 \mathrm{f}$. Dissertação (Mestrado em Zootecnia) - Universidade Federal de Viçosa.

DOLBERG, F. Program in the utilization of urea - ammonia treated crop residues: nutritive dimensions and application of the technology on small farm. In: SIMPÓSIO INTERNACIONAL DE RUMINANTES, 1992, Lavras. Anais... Lavras: Sociedade Brasileira de Zootecnia, 1992. p.130-145.

EZEQUIEL, J.M.B.; QUEIROZ, M.A.A.; GALATI, R.L. et al. Processamento da cana-de-açúcar: efeitos sobre a digestibilidade, o consumo e a taxa de passagem. Revista Brasileira de Zootecnia, v.34, n.5, p.1704-1710, 2005.

FADEL, R.; ROSA, B.; OLIVEIRA, I.P. de. et al. Avaliação de diferentes proporções de água e de uréia sobre a composição bromatológica da palha de arroz. Ciência Animal Brasileira, v.4, n.2, p.101-107, 2003.

FADEL, R.; ROSA, B.; OLIVEIRA, I.P. et al. Valor nutritivo da palha de arroz amonizada com ovinos. Ciência Animal Brasileira, v.5, n.1, p.19-25, 2004.

FERNANDES, F.E.P.; GARCIA, R.; PIRES, A.J.V. et al. Ensilagem de sorgo forrageiro com adição de ureia em dois períodos de armazenamento. Revista Brasileira de Zootecnia, v.38, n.11, p.2111-2115, 2009.

FERNANDES, L.O.; REIS, R A; RODRIGUES, L.R.A. et al. Qualidade do feno de Brachiaria decumbens Stapf. submetido ao tratamento com amônia anidra ou uréia. Revista Brasileira de Zootecnia, v.31, n.3, p.1325-1332, 2002 (supl.).

FERREIRA, A.R. Avaliação de aditivos químicos na ensilagem de cana-de-açúcar. 2005. 36f. Dissertação (Mestrado em Produção de Ruminantes) - Universidade Estadual do Sudoeste da Bahia, Itapetinga.

FERREIRA, L.S.; SANTOS, V.P.; BITTAR, C.M.M. et al. Degradabilidade in situ da matéria seca e da fração fibra em detergente neutro da cana-de-açúcar fresca ou ensilada e da silagem de milho em ambientes ruminais. In: REUNIÃO ANUAL DA SOCIEDADE BRASILEIRA DE ZOOTECNIA, 44., 2007, Jaboticabal. Anais... Jaboticabal: Sociedade Brasileira de Zootecnia, 2007. (CD-ROM).

FREITAS, A.W.P.; PEREIRA, J.C.; ROCHA, F.C. et al. Características da silagem de cana-de-açúcar tratada com inoculante bacteriano e hidróxido de sódio e acrescida de resíduo da colheita de soja. Revista Brasileira de Zootecnia, v.35, n.1, p.48-59, 2006.

GARCIA, R.; PIRES, A.J.V. Amonização de forragens. In: SEMANA DO FAZENDEIRO. Viçosa, MG: UFV, 1998. 7p.

HOMB, T. Wet treatment with sodium hidroxide. In: SUNDSTOL, F.; OWEN, E. (Eds.) Straw and other fibrous by-products as feed. Amsterdam: Elsevier Science Publishers, 1984. p.106-126.

LOPES, W.B.; PIRES, A.J.V.; SALES, R.M.P. et al. Capim-elefante tratado com óxido de cálcio e, ou hidróxido de sódio. In: REUNIÃO ANUAL DA SOCIEDADE BRASILEIRA DE ZOOTECNIA, 44., 2007, Jaboticabal. Anais... Jaboticabal: Sociedade Brasileira de Zootecnia, 2007. (CD-ROM).

MARTINES, E. Processo de hidrólise da cana para alimentação de vacas em lactação. Instituto de Tecnologia 
do Paraná - TECPAR. Disponível em: <http://www.sbrt.ibict.br>. Acesso em: 20/9/2007.

MORAES, K.A.K. Desempenho produtivo de novilhas de corte alimentadas com cana-de-açúcar tratada com óxido de cálcio e diferentes ofertas de concentrado. 2006. 60f. Tese (Mestrado em Zootecnia) - Universidade Federal de Viçosa, Viçosa, MG

MORAES, K.A.K.; VALADARES FILHO, S.C.; MORAES, H.B.K. et al. Cana-de-açúcar tratada com óxido de cálcio fornecida com diferentes níveis de concentrado para novilhas de corte em confinamento. Revista Brasileira de Zootecnia, v.37, n.7, p.1293-1300, 2008.

MOTA, D.A.; OLIVEIRA, M.D.S.; DOMINGUES, F.N. et al. Avaliação da composição bromatológica da cana-de-açúcar submetida ou não a hidrólise in naturacom diferentes tipos de cal. In: REUNIÃO ANUAL DA SOCIEDADE BRASILEIRA DE ZOOTECNIA, 44., 2007, Jaboticabal. Anais... Jaboticabal: Sociedade Brasileira de Zootecnia, 2007. (CD-ROM).

NEIVA, J.N.M.; GARCIA, R.; VALADARES FILHO, S.C. et al. Características fermentativas das silagens de milho amonizadas. Revista Brasileira de Zootecnia, v.27, n.3, p.474-480, 1998a.

NEIVA, J.N.M.; GARCIA, R.; VALADARES FILHO, S.C. et al. Desempenho de bovinos de corte alimentados com dietas à base de silagens e rolão de milho amonizados. Revista Brasileira de Zootecnia, v.27, n.3, p.466-473, 1998b.

OLIVEIRA, M.D.S.; DOMINGUES, F.N.; SANTOS, J. et al. Avaliação da cal hidratada (hidróxido de cálcio) como agente hidrolisante da cana-de-açúcar sob diferentes tratamentos. In: REUNIÃO ANUAL DA SOCIEDADE BRASILEIRA DE ZOOTECNIA, 44., 2007, Jaboticabal. Anais... Jaboticabal: Sociedade Brasileira de Zootecnia, 2007. (CD-ROM).

PANCOTI, C.G.; CAMPOS, M.M.; BORGES, A.L.C.C. et al. Consumo e digestibilidade aparente da matéria seca, matéria orgânica e consumo de matéria seca digestível de dietas de cana-de-açúcar sem ou com adição de óxido de cálcio com diferentes níveis de inclusão de uréia em ovinos. In: REUNIÃO ANUAL DA SOCIEDADE BRASILEIRA DE ZOOTECNIA, 44., 2007, Jaboticabal. Anais... Jaboticabal: Sociedade Brasileira de Zootecnia, 2007. (CD-ROM).

PEDROSO, A.F.; NUSSIO, L.G.; LOURES, D.R.S. et al. Efeito do tratamento com aditivos químicos e inoculantes bacterianos nas perdas e na qualidade de silagens de cana-de-açúcar. Revista Brasileira de Zootecnia, v.36, n.3, p.558-564, 2007.

PIRES, A.J.V.; GARCIA, R.; CECON, P.R. et al. Amonização da quirera de milho com alta umidade. Revista Brasileira de Zootecnia, v.28, n.6, p.1186-1193, 1999.

PIRES, A.J.V.; GARCIA, R.; SOUZA, A.L. et al. Avaliação do consumo de silagens de sorgo tratadas com amônia anidra e, ou, sulfeto de sódio na alimentação de novilhas 3/4 Indubrazil/ Holandês. Revista Brasileira de Zootecnia, v.32, n.6, p.1525-1531, 2003.

PIRES, A.J.V.; GARCIA, R.; VALADARES FILHO, S.C. et al. Novilhas alimentadas com bagaço de cana-de-açúcar tratado com amônia anidra e, ou, sulfeto de sódio. Revista Brasileira de Zootecnia, v.33, n.4, p.1078-1085, 2004.

PIRES, A.J.V.; REIS, R.A.; CARVALHO, G.G.P. et al. Bagaço de cana tratado com hidróxido de sódio. Revista Brasileira de Zootecnia, v.35, n.3, p.953-957, 2006 a.

PIRES, A.J.V.; REIS, R.A.; SIQUEIRA, G.R. et al. Composição química do feno de Brachiaria brizantha amonizado em diferentes umidades. Archivos de Zootecnia, v.55, n.212, p.393-396, 2006b.

PORTO, P.P.; SALIBA, E.O.S.; GONÇALVES, L.C. et al. Frações da parede celular e digestibilidade in vitro da matéria seca de três genótipos de girassol ensilados com aditivos. Arquivo Brasileiro de Medicina Veterinária e Zootecnia, v.58, n.1, p.99-107, 2006.
REIS, R.A.; GARCIA, R.; QUEIROZ, A.C. et al. Efeitos da amonização sobre a qualidade do feno de gramíneas tropicais. Pesquisa Agropecuária Brasileira, v.26, n.8, p.1183-1191, 1991.

REIS, R.A.; PANIZZI, R.C.; ROSA, B. et al. Efeitos da amonização sobre a ocorrência de fungos, composição química e digestibilidade in vitro de fenos de grama seda (Cynodon dactylon (L.) Pers). Revista Brasileira de Zootecnia, v.26, n.3, p.454460, 1997.

REIS, R.A.; ROSA, B.; MOREIRA, A.L. Tratamento químico de volumosos: amonização. In: SIMPÓSIO SOBRE MANEJO ESTRATÉGICO DA PASTAGEM, 1., 2002, Viçosa, MG. Anais... Viçosa, MG: UFV/DZO, 2002. 469p.

RIBEIRO, L.S.O.; PIRES, A.J.V.; CARVALHO, G.G.P. et al. Degradabilidade da matéria seca e da fração fibrosa da cana-deaçúcar tratada com hidróxido de sódio ou óxido de cálcio. Revista Brasileira de Saúde e Produção Animal, v.10, n.3, p.573-585, 2009.

RIBEIRO, L.S.O.; PIRES, A.J.V.; PINHO, B.D. et al. Teor de matéria seca e constituintes da parede celular da cana-de-açúcar hidrolisada com aditivos alcalinos. In: REUNIÃO ANUAL DA SOCIEDADE BRASILEIRA DE ZOOTECNIA, 44., 2007, Jaboticabal. Anais... Jaboticabal: Sociedade Brasileira de Zootecnia, 2007. (CD-ROM).

ROSA, B.; FADEL, R. Uso de amônia anidra e de uréia para melhorar o valor alimentício de forragens conservadas. In: SIMPÓSIO SOBRE PRODUÇÃO E UTILIZAÇÃO DE FORRAGENS CONSERVADAS, 1, Maringá, 2001. Anais... Maringá: UEM/ CCA/DZO, 2001. 319p.

ROSA, B.; REIS, R.A.; RESENDE, K.T. et al. Valor nutritivo do feno de Brachiaria decumbens Stapf cv. Basilisk submetido a tratamento com amônia anidra ou uréia. Revista Brasileira de Zootecnia, v.27, p.815-822, 1998.

ROTH, A.P.T.; REIS, R.A.; SIQUEIRA, G.R. et al. Composição química de silagens de cana-de-açúcar ensilada em diferentes tempos após a queima e tratadas com aditivos. In: REUNIÃO ANUAL DA SOCIEDADE BRASILEIRA DE ZOOTECNIA, 44., 2007, Jaboticabal. Anais... Jaboticabal: Sociedade Brasileira de Zootecnia, 2007. (CD-ROM).

SANTOS, J.; CASTRO, A.L.A.; PAIVA, P.C.A. et al. Efeito dos tratamentos físicos e químicos no resíduo de lixadeira do algodão. Ciência e Agrotecnologia, v.28, n.4, p.919-923, 2004.

SARMENTO, P.; GARCIA, R.; PIRES, A.J.V. et al. Grãos de soja como fonte de urease na amonização do bagaço de cana-deaçúcar com uréia. Scientia Agricola, v.58, n.2, p.223-227, 2001.

SILVA, H.G.O.; PIRES, A.J.V.; CUNHA NETO, P.A. et al. Digestibilidade de dietas contendo silagem de capim-elefante amonizado e farelo de cacau ou torta de dendê em ovinos. Revista Brasileira de Zootecnia, v.36, n.2, p.499-506, 2007.

SIQUEIRA, G.R.; REIS, R.A.; SCHOCKEN-ITURRINO, R.P. et al. Associação entre aditivos químicos e bacterianos na ensilagem de cana-de-açúcar. Revista Brasileira de Zootecnia, v.36, n.4, p.789-798, 2007.

TEIXEIRA JR., D.J.; OLIVEIRA, M.D.S.; MOTA, D.A. et al Efeito da cal virgem (óxido de cálcio) como agente hidrolisante sobre a composição bromatológica da cana-de-açúcar após 24 horas de tratamento. In: REUNIÃO ANUAL DA SOCIEDADE BRASILEIRA DE ZOOTECNIA, 44., 2007, Jaboticabal. Anais... Jaboticabal: Sociedade Brasileira de Zootecnia, 2007. (CD-ROM).

VIEIRA, F.A.P.; BORGES, I.; STEHLING, C.A.V. et al. Qualidade de silagens de sorgo com aditivos. Arquivo Brasileiro de Medicina Veterinária e Zootecnia, v.56, n.6, p.764-722, 2004.

VILELA, H. Melaço em pó com volumosos na alimentação de éguas em reprodução. Artigos Científicos, 2007. Disponível em:<http://www.agronomia.com.br/conteudo/ artigos/artigos_melaco_po_eguas_reproducao.htm/>. Acesso em: 4/5/2007. 